\title{
PENGAWASAN KREDIT PT. BANK PERKREDITAN RAKYAT KOTO SEBELAS TARUSAN
}

\author{
Jaka Hefrimal Putra, Afriyeni \\ Akademi Keuangan dan Perbankan Padang \\ Afriyeni.yen@gmail.com
}

\begin{abstract}
ABSTRAK
Tujuan dari penelitian ini adalah untuk mengetahui Pengawasan Kredit PT. Bank Perkreditan Rakyat Koto Sebelas Tarusan. Dilakukan secara kualitatif yaitu dengan melakukan analisa terhadap data-data yang diberikan oleh PT. Bank Perkreditan Rakyat Koto Sebelas Tarusan mengenai Pengawasan Kredit. Aktivitas utama Bank Perkreditan Rakyat Koto Sebelas Tarusan adalah menyalurkan kredit, jenis-jenis kredit yang disalurkan adalah Kredit Harian, Kredit Mingguan, Kredit Investasi, Kredit Modal Kerja dan Kredit Musiman. Pengawasan kredit yang dilakukan oleh Bank Perkreditan Rakyat Koto Sebelas Tarusan dimulai dari tahap permohonan dengan memeriksa kelengkapan berkas kredit serta melakukan sistem pengawasan langsung terhadap usaha nasabah. Bagi debitur yang tidak membayar angsuran atau sudah terjadi penunggakan maka akan diberi surat peringatan. Berdasarkan data yang diperoleh kredit yang dilakukan PT. Bank Perkreditan Rakyat Koto Sebelas Tarusan kurang baik sehingga terjadi kredit bermasalah.
\end{abstract}

Kata Kunci: Pengawasan, Kredit

\section{LATAR BELAKANG}

Secara umum lembaga keuangan dapat dikelompokkan dalam dua bentuk yaitu bank dan bukan bank. Undang-undang RI No. 10 Tahun 1998 Tentang Perbankan mengemukakan bahwa bank adalah badan usaha yang menghimpun dana dari masyarakat dalam bentuk simpanan dan menyalurkannya kepada masyarakat dalam bentuk kredit atau bentuk-bentuk lainnya dalam rangka meningkatkan taraf hidup rakyat banyak.

Dalam persaingan dunia bisnis terutama dalam lembaga keuangan perlu adanya pengawasan guna mempermudah terjadinya transaksi dalam pemberian kredit yang akan berimplikasi terhadap berbagai aspek, seperti : terhadap lembaga keuangan yang terlibat, aspek hukum pihak-pihak yang terkait, mekanisme penyelesaian risiko, yang kesemuanya itu dapat memberikan dampak kepada sistem lembaga keuangan dan perekonomian.

Pada dasarnya pengembangan perekonomian masyarakat, ditujukan pada dua pokok yaitu meningkatkan kemampuan produksi, serta terciptanya lapangan kerja baru bagi angkatan kerja yang setiap tahunnya meningkat, namun dikarenakan adanya keterbatasan modal produksi dalam usaha meningkatkan 
perekonomian tersebut, bantuan dari bank dalam bentuk tambahan modal atau yang disebut dengan kredit yang sangat dibutuhkan. Hal ini disebabkan karena kebutuhan masyarakat manusia yang beraneka ragam selalu meningkat, sementara kemampuan untuk mencapai sesuatu yang diinginkan terbatas sehingga terjadilah kesenjangan antara kemampuan dan cita-cita.

Bank merupakan salah satu lembaga keuangan yang mempunyai peranan yang sangat penting bagi aktivitas perekonomian. Dalam upaya mencapai tujuan pembangunan yang dilakukan, baik kebijakan fiskal maupun kebijakan moneter yang dilakukan oleh pemerintah yaitu di bidang perbankan. Bank sebagai badan usaha yang berorientasi pada pencapaian keuntungan ( Profit Oriented ). Dalam hal ini fungsi utama bank adalah sebagai perantara antara masyarakat kelebihan dana dengan masyarakat kekurangan dana, maka usaha pokok yang dilaksanakan bank adalah kegiatan-kegiatan pada sektor perkreditan, atau penyaluran dana. Sehingga secara otomatis pendapatan bank yang terbesar diperoleh dari sektor perkreditannya. Semakin tinggi volume perkreditannya, maka semakin besar pula kemungkinan suatu bank untuk pencapaian profitabilitas. Dengan demikian perlu dilakukan pengelolaan perbankan secara profesional terutama dalam sektor perkreditannya. Dengan dilakukannya pengelolaan kredit secara profesional diharapkan dapat meningkatkan likuiditas dan profitabilitas bank.

Manajemen kredit sangat penting dilakukan dalam penyaluran dana agar bank tidak mengalami kredit bermasalah karena pada kenyataannya kredit yang diberikan kepada nasabah banyak mengalami kendala, salah satu alat yang tepat dan efektif dalam menangani masalah kredit, yaitu melaksanakan fungsi pengawasan dengan baik. Pengawasan kredit menurut Hasibuan (2001:105) adalah usaha-usaha untuk menjaga kredit yang diberikan tetap lancar, produktif dan tidak macet. Lancar dan produktif artinya kredit itu dapat ditarik kembali bersama bunganya sesuai dengan perjanjian yang telah disetujui kedua belah pihak. Hal ini penting karena jika terjadi kredit macet, maka bank yang bersangkutanlah yang akan menanggung kerugiannya. Adapun faktor-faktor penyebab terjadinya kredit bermasalah antara lain:

1. Kurangnya pengawasan internal

2. Kurangnya informasi calon nasabah

3. Kurangnya analisis kredit

4. Tidak adanya itikad baik dari nasabah

Untuk kelangsungan usaha bank sangat ditentukan oleh kesiapan bank untuk menghadapi risiko kerugian dari kredit yang disalurkan. Oleh karena itu bank perlu melakukan pengawasan lebih awal terhadap nasabah yang akan mendapatkan fasilitas kredit.

Bank Perkreditan Rakyat Koto Sebelas Tarusan merupakan salah satu lembaga keuangan yang ikut berpartisipasi dalam mewujudkan pemerataan kesejahteraan masyarakat melalui pemberian fasilitas kredit pada masyarakat umum dan pengusaha pada khususnya. Pelaksanaan pengawasan yang dilakukan oleh PT.Bank Perkreditan Rakyat Koto Sebelas Tarusan didasarkan pada penilaian atas laporan-laporan dan kelengkapan file-file serta pemeriksaan langsung ketempat usaha nasabah. Dengan dilakukan pengawasan ini, maka PT. Bank Perkreditan Rakyat Koto Sebelas Tarusan akan dapat menilai apakah kredit 
yang diberikan oleh bank pada nasabah benar-benar digunakan sesuai dengan proposal yang diajukan oleh nasabah.

Untuk mengantisipasi terjadinya kredit bermasalah maka pengawasan kredit mutlak dilakukan pihak bank karena berdampak pada tingkat kesehatan bank dan kelangsungan hidup bank itu sendiri.

\section{Tabel 1}

Kolektibilitas Pengembalian Kredit

PT. Bank Perkreditan Rakyat Koto Sebelas Tarusan

Tahun 2008 - 2012

\begin{tabular}{|l|c|c|c|c|c|c|c|c|c|c|}
\hline \multirow{2}{*}{ Keterangan } & \multicolumn{2}{|c|}{ Tahun 2008 } & \multicolumn{2}{c|}{ Tahun 2009 } & \multicolumn{2}{c|}{ Tahun 2010 } & \multicolumn{2}{c|}{ Tahun 2011 } & \multicolumn{2}{c|}{ Tahun 2012 } \\
\cline { 2 - 11 } & $\begin{array}{c}\text { Total kredit } \\
(000)\end{array}$ & $\%$ & $\begin{array}{c}\text { Total kredit } \\
(000)\end{array}$ & $\%$ & $\begin{array}{c}\text { Total kredit } \\
(000)\end{array}$ & $\%$ & $\begin{array}{c}\text { Total kredit } \\
(000)\end{array}$ & $\%$ & $\begin{array}{c}\text { Total kredit } \\
(000)\end{array}$ & $\%$ \\
\hline Lancar & $1.646 .425,5$ & 96,14 & $1.703 .188,3$ & 94,51 & $2.107315,1$ & 92,52 & 2.259 .506 & 89,76 & $1.881 .817,1$ & 82,32 \\
\hline $\begin{array}{l}\text { Kurang } \\
\text { lancar }\end{array}$ & - & 0 & $33.339,3$ & 1,85 & $46.237,1$ & 2,03 & $76.273,5$ & 3,03 & $139.901,9$ & 6,12 \\
\hline Diragukan & $4.281,3$ & 0,25 & - & 0,00 & $38.492,9$ & 1,69 & $43.800,6$ & 1,74 & $81.380,8$ & 3,56 \\
\hline Macet & $61.822,2$ & 3,61 & $65.597,4$ & 3,64 & $85.640,9$ & 3,76 & $137.694,9$ & 5,47 & $182.878,2$ & 8,00 \\
\hline Total & 1.712 .529 & 100 & 1.802 .125 & 100 & 2.277 .686 & 100 & 2.517 .275 & 100 & 2.285 .978 & 100 \\
\hline
\end{tabular}

Sumber : PT. Bank Perkreditan Rakyat Koto Sebelas Tarusan

Berdasarkan uraian diatas dapat kita lihat pada kolom 3 dan 4 kredit yang dilakukan PT. Bank Perkreditan Rakyat Koto Sebelas Tarusan kurang baik, sehingga terjadi kredit bermasalah. Maka dari itu penulis tertarik untuk mengetahui lebih dalam sejauh mana peranan pengawasan kredit yang dilakukan PT. Bank Perkreditan Rakyat Koto Sebelas Tarusan.

Melihat pentingnya pengawasan kredit dan supaya nasabah konsisten terhadap perjanjian yang telah disepakati sebelumnya, maka penulis tertarik untuk melakukan penelitian dengan judul "Pengawasan Kredit PT. Bank Perkreditan Rakyat Koto Sebelas Tarusan".

\section{METODE PENELITIAN}

1) Objek Penelitian

Yang menjadi objek dari penelitian adalah PT. Bank Perkreditan Rakyat Koto Sebelas Tarusan, yang berlokasi di Jl. Dr. Mohd. Zein No. 113 Komp. Pasar Tarusan Kecamatan Koto Sebelas Tarusan.

2) Jenis dan Sumber Data

Dalam metode penelitian ini digunakan 2 jenis data, yaitu:

a. Data primer adalah data-data yang diperoleh dari wawancara langsung pada pihak yang bersangkutan pada PT. Bank Perkreditan Rakyat Koto Sebelas Tarusan

b. Data sekunder adalah data-data yang diperoleh secara tidak langsung dari sumber-sumber lain di antaranya artikel dan data-data tertulis serta datadata tambahan yang diberikan oleh pihak bank.

3) Teknik Pengumpulan Data

Untuk mengumpulkan data-data yang diperlukan dalam penelitian ini, maka digunakan dua cara yaitu : 
a. Field Research (Studi Lapangan)

Pada studi lapangan, dilakukan studi langsung ke PT. Bank Perkreditan Rakyat Koto Sebelas Tarusan agar didapatkan data-data serta keteranganketerangan yang diperlukan dalam penelitian.

b. Library Research (Studi Kepustakaan)

Mengumpulkan data-data dan teori-teori yang berkaitan dengan masalah yang dibahas melalui literatur-literatur yang ada baik berupa buku-buku ataupun majalah-majalah ilmiah yang berkaitan dengan penelitian.

4) Teknik Analisa Data

Dilakukan secara kualitatif yaitu dengan melakukan analisa terhadap data data yang diberikan oleh PT. Bank Perkreditan Rakyat Koto Sebelas Tarusan mengenai Pengawasan Kredit.

\section{TINJAUAN LITERATUR \\ Pengertian Bank}

Bank merupakan salah satu bentuk lembaga keuangan yang berperan sebagai lembaga keuangan (financial intermediary) antara pihak-pihak yang memiliki kelebihan dana (surplus unit) dengan pihak-pihak yang memerlukan dana, serta sebagai lembaga yang berfungsi memperlancar lalu lintas pembayaran. Menurut UU Nomor 10 tahun 1998 tentang perbankan, bahwa bank adalah badan usaha yang menghimpun dana dari masyarakat dalam bentuk kredit atau bentuk lainnya dalam rangka meningkatkan taraf hidup rakyat banyak.

\section{Pengertian Kredit}

Istilah kredit adalah berasal dari bahasa Yunani "credere", yang berarti kepercayaan. Kredit tanpa kepercayaan tidak mungkin bisa terjadi. Dalam dunia perbankan, kepercayaan dapat diberikan atau diterima dalam bentuk uang. Istilah yang biasa dipergunakan dalam dunia perbankan adalah untuk pemberi kredit disebut kreditur, sedangkan untuk penerima kredit disebut debitur.

Maksud dari sipemberi kredit adalah ia percaya kepada sipenerima kredit bahwa kredit yang disalurkannya pasti akan dikembalikan sesuai perjanjian. Sedangkan bagi penerima kredit merupakan penerimaan kepercayaan sehingga mempunyai kewajiban untuk membayar sesuai jangka waktu yang telah ditentukan.

Menurut UU perbankan No 10 tahun 1998 yang dimaksud dengan kredit adalah penyediaan uang atau tagihan yang dapat dipersamakan dengan itu berdasarkan persetujuan atau kesepakatan pinjam meminjam antara bank dengan pihak lain yang mewajibkan pihak peminjam untuk melunasi hutangnya setelah jangka waktu tertentu dengan pemberian bunga.

Adapun unsur-unsur yang terkandung dalam pemberian suatu fasilitas kredit menurut Kasmir (2003 : 94) adalah sebagai berikut :

a. Kepercayaan

Yaitu keyakinan pemberi kredit bahwa prestasi yang diberikannya baik dalam bentuk uang, barang, atau jasa akan benar-benar diterimanya kembali dalam jangka waktu tertentu dimasa yang akan datang. 
b. Kesepakatan

Disamping unsur percaya didalam kredit juga mengandung unsur kesepakatan antara pemberi kredit dengan penerima kredit. Kesepakatan ini dituangkan dalam suatu perjanjian dimana masing-masing pihak menandatangani hak dan kewajibannya masing-masing.

c. Jangka Waktu

Setiap kredit yang diberikan memiliki jangka waktu tertentu, jangka waktu ini mencakup masa pengembalian kredit yang telah disepakati. Hampir dapat dipastikan bahwa tidak ada kredit yang tidak memiliki jangka waktu.

d. Resiko

Adanya suatu tenggang pengembalian akan menyebabkan suatu resiko tidak tertagihnya suatu kredit. Resiko ini merupakan tanggungan bank, baik resiko yang sengaja atau tidak sengaja yang dilakukan oleh nasabah.

e. Balas Jasa

Merupakan keuntungan atas pemberi suatu kredit atau jasa yang disebut dengan bunga.

\section{Pengertian Pengawasan Kredit}

Pengawasan merupakan fungsi pokok dari manajemen. Pengawasan kredit itu merupakan suatu proses internal control mulai saat permohonan sampai dengan kredit dilunasi. Pengawasan kredit diartikan salah satu fungsi manajemen berupaya untuk menjaga dan mengamankan kredit itu sebagai kekayaan bank dan dapat mengetahui asumsi-asumsi dasar persetujuan, kredit itu akan tercapai atau malah terjadinya penyimpangan.

\section{Fungsi dan Tujuan Pengawasan}

Secara umum fungsi pengawasan kredit dapat dijelaskan sebagai berikut :

a. Pencegahan Dini (early warning)

Yaitu dari indikasi penyimpangan yang dapat merugikan bank dan gagalnya usaha nasabah.

b. Pengawasan Melekat (built in control)

Yaitu pengawasan rutin oleh pejabat terkait atas setiap sesuai proses kredit sesuai dengan sistem dan prosedur yang berlaku.

Fungsi pengawasan kredit adalah sebagai alat kendali apakah dalam pemberian kredit telah dilaksanakan dengan perencanaan maupun ketentuan-ketentuan yang telah ditetapkan dibidang perkreditan. Pelaksanaan fungsi pengawasan merupakan tanggung jawab setiap level manajemen pada masing- masing bank. Dengan demikian, pada hakikatnya kegiatan pengawasan kredit bersifat "melekat" didalam masing-masing level manajemen atau individu tersebut.

Adapun tujuan dari pengawasan kredit adalah sebagai berikut :

a. Patuh dan taat terhadap ketentuan perkreditan yang berlaku.

b. Meminimalkan kerugian bank oleh para pejabat bank dan pihak peminjam.

c. Terlaksananya administrasi dan dokumentasi kredit secara lebih baik.

d. Memperbaiki performance bank dan menjamin kelangsungan hidup bank.

e. Meningkatkan efesiensi dan efektifitas pengelolaan kredit. 


\section{Teknik Pengawasan Kredit}

Teknik pengawasan merupakan pendekatan-pendekatan yang dipakai manajemen suatu bank dalam melakukan kegiatan pengawasan. Beberapa teknik pengawasan kredit dijelaskan sebagai berikut :

1) Control By Exception (pengawasan terhadap hal-hal yang masih menyimpang).

Mengingat ruang lingkup pengawasan kredit sangat luas, maka pelaksanaan kredit harus berjalan dengan efisiensi. Dalam pelaksanaannya harus mengikuti suatu prinsip yang disebut control by exeption. Dalam prinsip ini sangat mudah dapat dikemukakan bahwa kegiatan pengawasan itu perlu ditekankan pada hal-hal yang bersifat exception.

Adakalanya kegiatan pengawasan kredit ditekankan pada hal-hal yang memerlukan perhatian khusus, pendekatan yang bersifat khusus tersebut, dapat dilakukan dengan menggunakan analisis SWOT, yaitu sebagai berikut :

a. Strengtness point, yaitu melakukan analisis atau pengamatan atas suatu objek untuk identifikasi sebagai hal-hal positif yang merupakan kekuatan yang dapat diandalkan.

b. Weaknesses point, yaitu mencari dan mengelompokan kelemahan yang ada kekurangan dan hal-hal yang bersifat negatif pada objek pengawasan.

c. Opportunities (peluang), mengelompokan peluang yang ada dan memanfaatkan sebesar-besarnya peluang tersebut menjadi keuntungan bank.

d. Threats (ancaman), yaitu adanya pembatasan-pembatasan atau ancaman yang membahayakan kelangsungan bank atau dapat menimbulkan kerugian.

Maka sasaran dan intensitas pengawasan dititik beratkan kepada hal hal yang masih lemah (faktor internal) dan hal-hal yang membahayakan (faktor eksternal).

Jadi analisis SWOT ini merupakan alat yang sangat berguna bagi manajemen agar kegiatan-kegiatan pengawasan itu sendiri dapat berlangsung secara terarah dan efisiensi, dengan cara pengarahan pengawasan kepada hal-hal bersifat lemah dan yang membahayakan atau mengancam.

2) Pengawasan fisik yaitu pengawasan yang dilakukan dengan mengandalkan pemeriksaan langsung ditempat kegiatan usaha nasabah (On The Spot) terhadap aktifitas usaha yang telah dilakukan dan atas hal-hal yang telah dilaporkan. Secara umum sasaran pengawasan fisik adalah :

a. Personalia dan Organisasi

Personalia dan organisasi dalam perusahaan turut menentukan kemajuan perusahaan, oleh karena itu petugas yang melaksanakan On The Spot wajib menyelidikinya secara mendalam apakah kedua masalah ini telah memadai dengan aktifitas perusahaan.

b. Administrasi dan Keuangan Perusahaan

Penyelenggaraan administrasi dan keuangan suatu perusahaan dapat memberikan gambaran tentang bagaimana aktifitas perusahaan itu dijalankan. 
c. Alat-alat Produksi dan Aktifitas Produksi Situasi Lingkungan

Penelitian terhadap alat-alat produksi dan aktifitas produksi dapat dititk beratkan kepada beberapa hal yaitu lokasi usaha yang strategis dan jumlah alat produksi.

d. Barang Dagang, Bahan Baku dan Barang Setengah Jadi

Diadakan penelitian dan pengecekan atas laporan yang disampaikan oleh nasabah terhadap keadaan stock (jumlah dan jenis stock)

3) Monitoring Kredit

Pengawasan melalui laporan atau informasi intern dan ekstern yang dikombinasikan, untuk selanjutnya diambil langkah-langkah pengamanan secara dini bila terdapat hal atau masalah yang mengarah kepada timbulnya kerugian bank.

\section{Proses dan Jenis Pengawasan Kredit}

kegiatan pengawasan kredit mencakup unsur-unsur yang berupa langkah sebagai berikut :

a. Menetapkan Kriteria Pengawasan

Sebelum melakukan suatu pengawasan terhadap kredit suatu bank harus terlebih dahulu menetapkan kriteria pengawasan. Pengawasan kredit harus berhasil untuk menentukan dasar yang akan digunakan sebagai titik tolak dalam meliputi hubungan timbal balik antar variabel yang mempunyai hubungan sebab-akibat, sehingga dipahami adanya logika dalam pengawasan.

b. Menetapkan Standar Pengawasan

Berdasarkan kriteria-kriteria pengawasan sebagaimana telah ditetapkan dapat dibuat standar pengawasan yang digunakan sebagai norma untuk menilai hasil-hasil pelaksanaan kegiatan debitur.

c. Melakukan Proses Penilaian

Setelah perusahaan mengetahui atau menetapkan proses pengawasan bank juga melakukan proses penilaian. Tindakan ini dilakukan secara umum dan khusus dengan memperbandingkan kinerja, norma dan tujuan pemberian kredit.

Bila suatu bank telah melakukan monitoring dengan baik, berarti bank tersebut telah menjalankan sistem pengawasan dini, dimana deteksi dini dilakukan untuk mengetahui indikasi-indikasi penyimpangan yang merupakan potensi berbahaya bagi bank. Indikasi-indikasi penyimpangan dapat dideteksi melalui beberapa jenis monitoring.

Monitoring kredit dapat diklasifikasikan sebagai berikut :

a. On Desk Monitoring

Yaitu pemantauan melalui instrumen administratif yang dapat memberikan informasi mengenai gejala-gejala penyimpangan yang berdampak terhadap kolektibilitas kredit. Seperti gejala dari laporan keuangan nasabah, gejala dari perusahaan nasabah, gejala dari sikap nasabah, gejala dari sikap pejabat bank, gejala dari luar atau lingkungan.

b. On Site Monitoring

Yaitu pemantauan kredit langsung ketempat usaha nasabah.

On Site Monitoring terbagi atas dua : 


\section{1) On Site Monitoring Routine}

Sesuai dengan klasifikasi dan tingkat resiko nasabah (dilakukan tiga bulan sekali).

2) On Site Monitoring Insidentil

Sesuai dengan, terkait dengan gejala yang ditemui pada On Desk Monitoring atau bila ada tambahan/perpanjangan jangka waktu kredit.

Tujuan On Site Monitoring :

- Meneliti kebenaran data atau keterangan yang disampaikan nasabah.

- Meneliti secara langsung usaha nasabah.

- Secara psikologis mengingatkan nasabah, bahwa bank menaruh perhatian atas usaha nasabah.

- Mendidik nasabah untuk menyampaikan laporan sesuai kenyataan.

\section{Aspek-Aspek Pengawasan Kredit}

Pengawasan kredit mengandung aspek-aspek pokok, yaitu sebagai berikut :

1) Aspek Administratif

Yaitu meliputi penguasaan dan penata usahaan proses kegiatan kredit sejak awal sampai pelunasan.

2) Aspek Supervise

Yaitu secara terus-menerus mengikuti perkembangan kredit dan usaha nasabah, agar bank mampu mengetahui actual performance kredit yang tercermin pada kolektibilitasnya.

3) Aspek Penagihan

Penarikan kembali kredit sesuai jadwal dengan tidak mengganggu berjalannya kegiatan usaha nasabah, kecuali ada sinyal bahwa ada penurunan mutu kredit yang terus menerus agar bank terhindar dari kerugian.

\section{HASIL PENELITIAN}

Kegiatan utama Bank Perkreditan Rakyat Koto Sebelas Tarusan adalah menyalurkan dana dalam bentuk kredit kepada masyarakat terutama untuk pengusaha atau pedagang yang membutuhkan modal untuk pengembangan usahanya. Adapun jenis-jenis kredit yang disalurkan oleh PT. Bank Perkreditan Rakyat Koto Sebelas Tarusan adalah sebagai berikut :

1) Kredit Harian

a) Plafon maksimum sebesar Rp 2.000.000.00,-

b) Bunga pertahun $26 \%$

c) Provisi tidak ada

d) Administrasi $1 \% \mathrm{X}$ plafon

e) Jangka waktu 60 hari sampai 110 hari

f) Cara pembayaran pokok + bunga (dibayar setiap hari)

g) Tabungan beku tidak ada

h) Persyaratan

- Foto copy KTP suami dan istri

- Foto copy kartu keluarga

- Pas foto warna 
i) Jaminan / Agunan

- Peralatan rumah tangga

- Barang dagang debitur

j) Materai dibebankan kepada nasabah sesuai ketentuan

k) Denda 0,1\% per hari dari jumlah tunggakan

2) Kredit Mingguan

a) Plafon maksimum sebesar Rp. 2.500.000.00,-

b) Bunga pertahun $25 \%$

c) Provisi tidak ada

d) Administrasi $1 \% \mathrm{X}$ Plafon

e) Jangka waktu 10 minggu

f) Cara pembayaran pokok + bunga (dibayar setiap minggu)

g) Tabungan beku 5\% dari plafon

h) Persyaratan

- Foto copy KTP suami dan istri

- Foto copy kartu keluarga

- Pas foto warna

i) Jaminan / Agunan

- Peralatan rumah tangga

- Barang dagang debitur

j) Materai dibebankan kepada nasabah sesuai ketentuan

k) Denda 0,1\% perhari dari jumlah tunggakan

3) Kredit 15 Hari

a) Plafon maksimum sebesar Rp. 3.000.000.00,-

b) Bunga pertahuan $24 \%$

c) Provisi tidak ada

d) Administrasi $1 \% \mathrm{X}$ plafon

e) Jangka waktu 5 bulan

f) Cara pembayaran pokok + bunga (dibayar setiap 15 hari)

g) Tabungan beku 5\% dari dari plafon

h) Persyaratan

- Foto copy suami dan istri

- Foto copy kartu keluarga

- Dan sesuai SOP kredit

i) Jaminan / Agunan

- BPKB kendaraan roda dua diatas tahun 1990

- Peralatan rumah tangga

- Barang dagangan debitur

j) Materai dibebankan kepada nasabah sesuai ketentuan

k) Denda $0,1 \%$ perhari dari jumlah tunggakan

4) Kredit Modal Kerja dan Investasi

a) Plafon Rp.1.000.000.00,- sampai Rp.25.000.000.00,-

b) Bunga pertahun $20 \%$

c) Provisi $1 \%$ sampai $2 \%$ dari plafon

d) Administrasi $1 \% \mathrm{X}$ plafon

e) Jangka waktu maksimal 5 tahun 
f) Cara pembayaran pokok + bunga (dibayar setiap bulan)

g) Tabungan beku 5\% dari plafon

h) Persyaratan

- Foto copy KTP suami dan istri

- Foto copy kartu keluarga

- Pas foto warna

- Dan sesuai SOP kredit

i) Jaminan / Agunan

- BPKB kendaraan roda dua dan roda empat diatas tahun 1990

- Sertifikat

j) Materai dibebankan kepada nasabah sesuai ketentuan

k) Denda 0,1\% perhari dari jumlah tunggakan

5) Kredit Konsumtif

a) Plafon Rp.1.000.000.00,- sampai Rp.2.500.000.00,-

b) Bunga pertahun $20 \%$

c) Provisi $2 \%$ dari plafon kredit

d) Administrasi $1 \% \mathrm{X}$ plafon kredit

e) Jangka waktu maksimal 5 tahun

f) Cara pembayaran pokok + bunga (dibayar setiap bulan)

g) Tabungan beku 5\% dari plafon

h) Persyaratan

- Foto copy KTP suami dan istri

- Foto copy kartu keluarga

- Pas foto warna

- Dan sesuai SOP kredit

i) Jaminan / Agunan

- BPKB kendaraan roda dua dan roda empat diatas tahun 1990

- Sertifikat

- SK terakhir dan surat kuasa potong gaji

j) Materai dibebankan kepada nasabah sesuai ketentuan

k) Denda $0,1 \%$ perhari dari jumlah tunggakan

6) Kredit Musiman

a) Plafon Rp.1.000.000.00,- sampai Rp.2.500.000.00,-

b) Bunga pertahun $20 \%$

c) Provisi $2 \%$ dari plafon kredit

d) Administrasi $1 \% \mathrm{X}$ plafon kredit

e) Jangka waktu maksimal 5 tahun

f) Cara pembayaran pokok + bunga (dibayar setiap bulan)

g) Tabungan beku 5\% dari plafon

h) Persyaratan

- Foto copy KTP suami dan istri

- Foto copy kartu keluarga

- Pas foto warna

- Dan sesuai SOP kredit

i) Jaminan / Agunan

- BPKB kendaraan roda dua dan roda empat diatas tahun 1990 
- Sertifikat

- SK terakhir dan surat kuasa potong gaji

j) Materai dibebankan kepada nasabah sesuai ketentuan

k) Denda $0,1 \%$ perhari dari jumlah tunggakan

Prosedur Pemberian Kredit PT. Bank Perkreditan Rakyat Koto Sebelas Tarusan

a. Permohonan Kredit

Pemohon kredit menyampaikan maksud untuk permohonan kredit dan kepadanya dijelaskan ketentuan dan syarat yang berlaku dalam pemberian kredit. Jika yang bersangkutan berkeinginan, kepadanya diminta untuk :

1) Mengisi permohonan kredit yang disediakan oleh bank.

2) Penyerahan dokumen lain yang berupa :

a) Foto copy kartu identitas berupa KTP suami dan istri calon debitur yang masih berlaku.

b) Foto copy kartu keluarga

c) Foto copy BPKB dan STNK kendaraan yang akan digunakan.

3) Formulir pendaftaran yang telah dilengkapi disimpan di bank.

b. Survey lapangan

1) Setiap permohonan kredit yang masuk akan diproses oleh pihak bank.

2) Proses terhadap permohonan ini dimulai dengan mengadakan survey lapangan terhadap sipemohon kredit.

3) Waktu pelaksanaan survey lapangan ditentukan oleh pihak bank.

c. Analisa dan rekomendasi kredit

1) Setiap permohonan kredit yang sudah disurvey lapangan akan dianalisa oleh Account Officer.

2) Analisa kredit disertai dengan rekomendasi yang sudah dibuat Account Officer diajukan kepada Direksi.

d. Administrasi kredit

1) Rekomendasi kredit yang sudah disetujui oleh Dewan Direksi akan diproses oleh petugas administrasi kredit untuk direalisasikan.

2) Petugas administrasi kredit akan mempersiapkan dokumen untuk keperluan realisasi kredit yaitu :

a) Perjanjian kredit antara debitur dengan pihak bank.

b) Surat kuasa dari debitur kepada pihak bank untuk pengikatan jaminan.

c) Bukti pembayaran terdiri dari :

1. Bukti pindah buku realisasi kredit.

2. Pembayaran provisi, administrasi, asuransi kredit.

3. Kartu pembayaran angsuran kredit.

3) Mengadministrasikan secara baik setiap dokumen yang sudah direalisasikan.

\section{Contoh Kasus :}

Bapak Handoko ingin meminjam uang di PT. Bank Perkreditan Rakyat Koto Sebelas Tarusan untuk penambahan modal perbengkelan sebesar Rp.15.000.000.00,- dalam jangka waktu tiga tahun. Maka hal-hal yang akan dilalui Bapak Handoko adalah sebagai berikut : 
1. Menyampaikan maksud dan keinginan kepada PT. Bank Perkreditan Rakyat Koto Sebelas Tarusan, maka pihak bank akan mewawancarai dan menjelaskan mengenai persyaratan kredit, terutama mengenai agunan. Bapak Handoko harus mempunyai jaminan atau agunan yang akan ditinggalkan bank.

2. Pihak PT. Bank Perkreditan Rakyat Koto Sebelas Tarusan akan menjelaskan mengenai angsuran harus dibayar setiap bulannya oleh Bapak Handoko yaitu sebagai berikut :

- Jenis kredit : Kredit Modal Kerja

- Angsuran : Pokok + Bunga

$$
\begin{aligned}
\text { Pokok } & =\frac{\text { Rp.15.000.000.00,- }}{36} \\
& =\text { Rp.416.667.00,- } \\
\text { Bunga } & =\text { Rp.15.000.000 x } \frac{20 \%}{12} \\
& =\text { Rp.250.000.00,- } \\
\text { Angsuran } & =\text { Rp.416.667.00,- +Rp.250.000.00,- } \\
& =\text { Rp.666.667.00,-- }
\end{aligned}
$$

Jadi kredit yang dibutuhkan Bapak Handoko adalah Kredit Modal Kerja dengan bunga $20 \%$ pertahun. Angsuran yang harus dibayar Bapak Handoko tiap bulannya adalah sebesar Rp.666.667.00,-. Jika Bapak Handoko setuju maka pihak bank akan memintanya untuk mengisi formulir permohonan kredit dan menyerahkan semua persyaratan kredit.

3. Pihak PT. Bank Perkreditan Rakyat Koto Sebelas Tarusan (Account Officer) akan melakukan survey ke tempat usaha Bapak Handoko untuk mengetahui kebenaran informasi yang disampaikannya.

4. Account Officer akan melakukan analisa terhadap hasil survey tersebut dengan membuat rekomendasi kredit untuk diajukan kepada Direksi.

5. Pihak bank akan menelpon Bapak Handoko untuk datang ke bank untuk membayar provisi dan administrasi kredit serta menanda tangani perjanjianperjanjian dan surat kuasa pengikatan jaminan.

6. Bapak Handoko menyerahkan agunan yaitu BPKB mobil yang asli. Selanjutnya pihak bank akan menjelaskan kembali mengenai ketentuanketentuan kredit yang berlaku di Bank Perkreditan Rakyat Koto Sebelas Tarusan dan kredit apabila Bapak Handoko mau mengikuti ketentuan kredit yang berlaku maka sudah dapat dicairkan.

Adapun proses pengawasan kredit yang dilakukan oleh PT. Bank Rakyat Koto Sebelas Tarusan adalah sebagai berikut :

1) Sebelum realisasi atau pencairan kredit :

a) Melihat kebenaran data-data dan kelengkapan berkas kredit.

b) Pemantauan usaha nasabah dan melihat laporan keuangannya.

c) Penilaian terhadap prinsip-prinsip pemberian kredit, yaitu prinsip $5 \mathrm{C}$ sehingga dapat menilai apakah calon debitur layak untuk diberi fasilitas kredit.

d) Penilaian terhadap jaminan atau agunan kredit yang mencakup hal-hal sebagai berikut : 
1. Bukti kepemilikan jaminan atau agunan kredit

2. Kondisi agunan (sehat atau tidak sehat) serta melakukan cek fisik terhadap agunan yang diberikan dengan tujuan mengantisipasi hal-hal yang akan merugikan bank.

3. Perkiraan nilai jual kembali, dengan tujuan untuk mengawasi apabila nantinya terjadi kredit macet maka terhadap agunan dapat menutupi hutang nasabah.

4. Pengikatan agunan atau jaminan dengan surat kuasa jual dan pengikatan lainnya dengan tujuan untuk mengatasi apbila nantinya debitur tidak membayar hutangnya maka ditempuh dengan jalur pengadilan.

2) Sesudah realisasi atau pencairan kredit.

Pengawasan kredit yang dilakukan PT. Bank Perkreditan Rakyat Koto Sebelas Tarusan adalah sistem pengawasan langsung yaitu sebagai berikut :

a) Pemantauan terhadap ketepatan nasabah dalam membayar angsuran kredit.

b) Pemantauan terhadap ketepatan penggunaan kredit

c) Pemantauan terhadap uasaha nasabah yang telah mendapatkan fasilitas kredit, dan yang dinilai adalah apakah suadah ada peningkatan jumlah penjualan serta penambahan barang modal.

d) Memberikan SP 1 (surat peringatan) kepada nasabah yang terlambat membayar angsuran atau menunggak 1 bulan.

e) Memberikan SP 2 (surat peringatan) kepada nasabah yang terlambat membayar angsuran atau menunggak 2 bulan.

f) Memberikan SP 3 (surat peringatan) kepada nasabah yang terlambat membayar angsuran atau menunggak 3 bulan.

g) Apabila pembinaan terhadap kredit bermasalah sudah tidak dapat dilakukan lagi, dan sudah terjadi kredit macet maka akan dilakukan penyitaan terhadap agunan atau jaminan yang diberikan oleh nasabah.

h) Barang agunan yang sudah disita akan dibuat dalam berita acara dan kepada nasabah akan diberi tenggang waktu untuk membayar kewajibannya, apabila dalam waktu yang ditentukan nasabah belum juga membayar kewajibannya maka akan dilakukan pelelangan agunan atau melalui urusan pengadilan.

\section{Perkembangan Jumlah Kredit PT. Bank Perkreditan Rakyat Koto Sebelas Tarusan}

Dana yang dihimpun oleh bank tersebut harus disalurkan kembali ke masyarakat dalam bentuk kredit. Hal ini dilakukan karena fungsi bank adalah sebagai lembaga perantara (intermediary) antara pihak-pihak yang kelebihan dana dengan pihak yang kekurangan dana, dan keuntungan bank diperoleh dari selisih antara harga beli dana tersebut setelah dikurangi dengan biaya operasional. Dengan demikian bank harus mampu menempatkan dana tersebut pada tempat yang paling menguntungkan serta bank juga harus melakukan fungsi pengawasan dengan baik.

Adapun perkembangan jumlah kredit yang disalurkan oleh PT. Bank Perkreditan Rakyat Koto Sebelas Tarusan setiap tahunnya, baik itu kredit harian, mingguan, kredit modal kerja, kredit investasi dan kredit konsumtif dapat dilihat pada tabel 2 dibawah ini : 
Tabel 2

Perkembangan Jumlah Kredit

PT. Bank Perkreditan Rakyat Koto Sebelas Tarusan

Tahun 2008 - 2012

\begin{tabular}{|c|l|c|}
\hline \multirow{2}{*}{ Tahun } & \multicolumn{1}{|c|}{ Total Kredit } & Pertumbuhan \% \\
\hline 2008 & Rp.1.712.529.000.00,- & - \\
\hline 2009 & Rp.1.802.125.000.00,- & 20,53 \\
\hline 2010 & Rp.2.277.686.000.00,- & 22,64 \\
\hline 2011 & Rp.2.517.275.000.00,- & 21,06 \\
\hline 2012 & Rp.2.285.978.000.00,- & 19,09 \\
\hline
\end{tabular}

Sumber : PT. Bank Perkreditan Rakyat Koto Sebelas Tarusan

Dari tabel 2 diatas dapat dilihat perkembangan jumlah kredit yang disalurkan oleh PT. Bank Perkreditan Rakyat Koto Sebelas Tarusan mengalami peningkatan yang cukup berarti, hal ini terlihat dari kenaikan jumlah kredit yang disalurkan meningkat pada tahun 2009 dengan jumlah Rp.1.802.125.000.00,dengan pertumbuhan sebesar 20,53\%. Pertumbuhan kredit yang paling kecil terjadi pada tahun 2012 dengan pertumbuhan sebesar 19,09\% dengan jumlah kredit sebesar Rp.2.285.978.000.00,-. Pada tahun sebelumnya 2011 kembali meningkat dengan pertumbuhan $21,06 \%$ dengan jumlah kredit sebesar Rp.2.517.275.000.00,- dan pada tahun 2010 mengalami pertumbuhan sebesar $22,64 \%$. Dilihat secara umum pertumbuhan terbesar terjadi pada tahun 2010 yaitu sebesar 22,64\% dengan jumlah kredit sebesar Rp.2.277.686.000.00,-.

\section{KESIMPULAN}

Berdasarkan atas pemahaman teori dan pembahasan yang telah diuraikan pada bab-bab sebelumnya, dapat dikemukakan beberapa kesimpulan sebagai berikut :

1. BPR Koto Sebelas Tarusan didirikan dengan Akta Nomor pendirian berdasarkan Akta Notaris Anasrul Jambi,SH. Di Jakarta No.284 pada tanggal 26 oktober 1991 dan berkedudukan dijalan DR.Mohd.Zein No.113 Komplek Pasar Tarusan KAN Nanggalo Kecamatan Koto Sebelas Tarusan Kabupaten Pesisir Selatan dengan modal awal Rp.1.000.000.000.00,- dan modal disetor Rp.305.000.000.00,-.

2. Aktivitas utama Bank Perkreditan Rakyat Koto Sebelas Tarusan adalah menyalurkan kredit, jenis-jenis kredit yang disalurkan adalah Kredit Harian, Kredit Mingguan, Kredit Investasi, Kredit Modal Kerja dan Kredit Musiman.

3. Pengawasan kredit yang dilakukan oleh Bank Perkreditan Rakyat Koto Sebelas Tarusan dimulai dari tahap permohonan dengan memeriksa kelengkapan berkas kredit serta melakukan sistem pengawasan langsung terhadap usaha nasabah. Bagi debitur yang tidak membayar angsuran atau sudah terjadi penunggakan maka akan diberi surat peringatan.

4. Berdasarkan data yang diperoleh kredit yang dilakukan PT. Bank Perkreditan Rakyat Koto Sebelas Tarusan kurang baik sehingga terjadi kredit bermasalah. 


\section{DAFTAR PUSTAKA}

Alanshari, F., \& Marlius, D. (2018). Prosedur Pemberian Kredit KPR Pada PT. Bank Tabungan Negara (Persero) TBK Cabang Pembantu Bukittinggi. https://doi.org/10.31227/osf.io/rsfhc

Amelia, L., \& Marlius, D. (2018). Pengendalian Kredit Dalam Upaya Menciptakan Bank Yang Sehat Pada PT. Bank Pembangunan Daerah Sumatera Barat Cabang Utama Padang. https://doi.org/10.31227/osf.io/kpc64

Andriani, B., \& Susanto, R. (2019). Pengawasan Kredit PT. Bank Perkreditan Rakyat (BPR) Ophir Pasaman Barat. https://doi.org/10.31219/osf.io/aunvc

Baiya, \& Fernos, J. (2019). Analisis Faktor-Faktor Penyebab Kredit Macet Pada Bank Nagari Cabang Siteba. https://doi.org/10.31227/osf.io/4xuks

Dermawan Indra, SE, (1992), Pengantar Uang dan Perbankan, PT. Bineka Cipta, Jakarta.

Darmawanto, \& Fernos, J. (2019). Prosedur Pemberian Kredit Pada Bank Nagari Cabang Sijunjung. https://doi.org/10.31227/osf.io/psqfy

Febriansyah, I., \& Afriyeni, A. (2019). Penyelesaian Kredit Bermasalah PT. Bank Pembangunan Daerah (BPD) Sumbar Cabang Alahan Panjang Kabupaten Solok. https://doi.org/10.31219/osf.io/vutmj

Firmansyah, A., \& Fernos, J. (2019). Analisis Kredit Bermasalah Dilihat Dari Standar Non Performing Loan (NPL) Pada PT. Bank Perkreditan Rakyat (BPR) Prima Mulia Anugrah Cabang Padang. https://doi.org/10.31227/osf.io/gcj94

Hasibuan, S.P. Malayu , Drs, (2002), Dasar-Dasar Perbankan, PT. Bumu Aksara.

Kasmir, (2000). “manajemen perbankan”, PT. Raja Grafindo Persada. Jakarta.

Mudrajad Kuncoro dan Suharjono, (2002), "Manajemen Perbankan Teori dan Aplikasi “. Edisi keempat, BPFE, Yogyakarta.

Mulyono, Teguh Padjo. 1996. Manajemen Perkreditan bagi Bank Komersil. Edisi ketiga. Yogyakarta : BTFE - UGM 
Pratama, D., \& Fernos, J. (2019). Prosedur Pelaksanaan Kredit Usaha Rakyat (KUR) Pada PT. Bank Nagari Cabang Padang. https://doi.org/10.31227/osf.io/ag68j

Purwatiningsih, 2001, Perbankan Masalah Perkreditan. Pradnya Paramita.

Rachnadi Usman, 2001, Aspek-aspek Hukum Perbankan di Indonesia, PT.Gramedia Pustaka Utama, Jakarta.

Sinungan. Muchdarsyah, (1999), "Dasar-dasar dan teknik manajemen kredit”. Bina Aksara, Jakarta.

Sumitro,Warkum. 1996. "Azas-Azas Perbankan dan Lembaga-Lembaga Terkait”. Jakarta: PT. Grafindo Persada.

$\begin{array}{llllll}\text { Undang - undang } & \text { Republik Indonesia Nomor } 7 & \text { Tahun } & 1992\end{array}$ diubah dengan Undang - undang Nomor 10 Tahun 1998, "Tentang Perbankan", Sinar Grafika, Jakarta, 2002,

Veithrizal Rivai dan Andria Permata Veithrizal (2005). "credit Management Handbook”. PT. Raja Grafindo Persada, Jakarta.

Widayati, R. (2019). Pelaksanaan Prinsip Kehati-Hatian Dalam Pemberian Kredit Konsumtif Pada Bank Nagari Cabang Siteba. https://doi.org/10.17605/OSF.IO/FZVXR

Widayati, R. (2019). Aktivitas Pemberian Kredit Komersil Pada Bank Nagari Cabang Sijunjung. https://doi.org/10.17605/OSF.IO/QTVZ9

Widayati, R. (2019). Pelaksanaan Kredit Pada Bank Perkreditan Rakyat LPN Pasar Baru Durian Sawahlunto. https://doi.org/10.17605/OSF.IO/5HPAB

Widayati, R. (2019). Upaya Penanganan Kredit Bermasalah Pada Bank Nagari Cabang Utama Padang. https://doi.org/10.17605/OSF.IO/YJ3KN 